\title{
Top Management Change, Succession Source and Enterprise Risk Decision Tendencies
}

\author{
Xin Wang \\ Business School, Nanjing Normal University, Nanjing, China \\ Email:1257518117@qq.com
}

How to cite this paper: Wang, X. (2019) Top Management Change, Succession Source and Enterprise Risk Decision Tendencies. Open Journal of Social Sciences, 7, 215-233.

https://doi.org/10.4236/jss.2019.711015

Received: November 1, 2019

Accepted: November 19, 2019

Published: November 22, 2019

Copyright $\odot 2019$ by author(s) and Scientific Research Publishing Inc. This work is licensed under the Creative Commons Attribution International License (CC BY 4.0).

http://creativecommons.org/licenses/by/4.0/

(c) (i) Open Access

\begin{abstract}
Based on Anomie theory and actual revenue management theory, this paper explores the relationship between $R \& D$ investment and short-term investment after administrative change/mandatory change. It is found that administrative change/mandatory change can significantly reduce $R \& D$ investment, and executive change can be significantly changed. Increasing short-term investments and mandatory changes in executives can significantly increase short-term investments. In addition, mandatory changes in executives can significantly reduce a company's R\&D investment. Successful sources can mitigate this relationship between administrative changes/mandatory changes and corporate $\mathrm{R} \& \mathrm{D}$ investments, and short-term investments in companies with executive change/mandatory changes. External successors will weaken changes/mandatory changes to R\&D investments, while internal successors will enhance the impact of change/mandatory changes on $\mathrm{R} \& \mathrm{D}$ investment. At the same time, external successors will reduce the positive impact of change/mandatory changes on short-term investments, and internal successors will enhance the positive impact of change/mandatory changes on short-term investments.
\end{abstract}

\section{Keywords}

Top Management Change, Succession Source, Enterprise Risk Decision Tendencies

\section{Introduction}

Relevant data of the fund industry show that there are 10 changes of senior executives involving more than general manager in the two months from March to may 2019. Frequent changes of senior executives will have an impact on the policy coherence of the enterprise. Due to the pressure of the external environment, 
the changes of senior executives in listed real estate enterprises are more frequent. According to relevant statistics, from January to May 2019, there were 76 changes in senior management of listed real estate and property companies, involving 121 people, 54 listed companies and 23 positions, including 8 changes in chairman and 7 changes in general manager. In the period of economic transformation in China, the listed companies often change their executives, and the phenomenon of "new officials take office three fires" often occurs. What kind of risk decisions will the successor executives make? In recent years, with the change of economic situation and the need of the internal development of enterprises, the change of senior management has become an inevitable problem.

The basic premise of anomie theory is driven by culture and society, which leads to the pressure of enterprises to achieve specific goals, replaces the standard control mechanism, and becomes the basis of enterprise moral behavior and decision-making. Morton defined "anomie" as that once the management behavior loses its principle, it will lead to the imbalance between the enterprise and the society [1]. He also believes that when there is a restraining target value in society, there will be a greater tendency to achieve a certain goal by deviating from social norms. After the change of senior managers, the new and old inside the enterprise alternate, and the collision between the new and old order provide the soil for the anomie behavior of the enterprise decision-makers. According to the anomie theory, the change of senior managers will cause the lack of a kind of internal standard in the short term. Before the establishment of new internal standard, managers will take deviant behavior, such as bribery, in order to improve the business performance of enterprises [2]. The existing literature is more from the perspective of performance expectation theory to explore the anomie behavior of enterprises, few literature to explore the change of executives and the anomie behavior of enterprises.

Since Moore, there has been a lot of literature on the relationship between executive change and earnings management [3]. The research of DEFOND and park found that listed companies use controllable accruals to smooth profits [4]. That is to say, the company with poor current performance and good future performance expectation will misappropriate future earnings with controllable accruals to increase current earnings and reduce the possibility of being dismissed [5] [6]; the company with good current performance but poor future performance expectation will use controllable accruals to reduce current earnings for future needs and reduce the possibility of being dismissed in the future see [7]. Zhu Xingwen [8] and other researchers found that companies with senior management changes have serious earnings management behavior of reducing profits in the year of senior management changes; Li Zengfu conducted research on Listed Companies in China in 1996-04, and found that enterprises will use accruals and real earnings management to smooth profits [9].

According to the theory of high-level echelon, the experience, values and personality characteristics of senior managers will greatly affect their decision-making in the face of problems [10] [11]. According to this theory, as the decision-maker, 
the experience of senior managers will determine the risk decision-making to a large extent. In the enterprises with mandatory changes, the successor executives will face relatively severe problems. He needs to stabilize the enterprise's decline in a short time and turn the enterprise's operating performance into profit.

Strong and Meyer [12] believe that different sources of senior managers' change of relay appointment will affect the change of earnings. When succession comes from outside the company, it is more likely to generate profit manipulation behavior of reducing the current year's earnings and increasing the later period's earnings. Du Xingqiang [13] and others empirically tested the impact of two factors on Earnings Management: the change of senior managers (chairman or general manager) and the source of succession of senior managers, and found that the change of senior managers led to significant negative earnings management behavior, compared with internal successors, external successors were more inclined to carry out negative earnings management. In the aspect of political governance, some studies have shown that the measures taken by the local and external leaders in the face of the same political events are quite different. Often, the internal leaders will adopt moderate measures that are conducive to the long-term governance of the township, while the external leaders will adopt violent suppression and other short-term effective means [14]. At the same time, empirical research on CEO succession of family business tells us that [15], family businesses with poor performance are more inclined to choose outsiders from family business than those from within family members, because they are eager to bring some vitality to the business through such changes. The existing literature focuses on the impact of mandatory executive change on corporate performance, but there is little research on the type of risk decision preference. This paper will use anomie theory and earnings management theory to explore the impact of executive change and further mandatory executive change on long-term risk decision-making and immediate risk decision-making, and enrich and supplement the relevant research of executive change on enterprise risk decision-making type preference.

\section{Theory and Assumptions}

\subsection{Senior Management Change and Risk Decision Type}

According to previous studies, we found that there is a correlation between executive change and earnings management, and the phenomenon of using controllable accrual income to smooth the overall profit is common in Listed Companies [3] [4]. At the same time, it is found that the company with the change of senior management has serious earnings management behavior of reducing profits in the year of the change of senior management. Vancil [16] believes that the first problem for new executives is to achieve performance goals in the first and second years of their term to reduce the risk of being replaced in the enterprise. As an investment with high cost and slow effect in a short period of time, $\mathrm{R} \& \mathrm{D}$ behavior of enterprises will become the primary goal of smooth profits. 
After the change of senior managers, the reduction of R\&D investment by successor senior managers can increase the cash flow in a short period of time, create a good phenomenon of enterprise operation, and gain the trust of the board of directors. At the same time, Morton's anomie theory found that the effectiveness of the old order will face challenges after the change of senior managers and before the establishment of the new order, creating conditions for anomie behavior [17]. In addition, according to earnings management theory, with the change of senior managers, new senior managers will face the demand of improving performance in the short term and reducing the risk of being replaced, so the desire to improve business performance is more urgent, which will breed greater misconduct. At the same time, based on the principal-agent theory, the successor executives can increase short-term investment, such as bribery expenditure [18], short-term investment can quickly improve the performance of the enterprise in the short term, solve the plight of the enterprise, but also leave a good impression on the board of directors, reduce the possibility of their dismissal. Based on this, we propose the hypothesis:

Hypothesis 1A: when the top management changes, the long-term risk decision-making tendency of the enterprise will be reduced, that is, the R\&D investment will be reduced.

Hypothesis 1B: the tendency of immediate risk decision-making increases when senior managers change, that is, short-term investment will increase.

According to the theory of high echelon team, as the decision maker, the experience of senior managers will determine the risk decision-making of enterprises to a large extent. In the enterprises with mandatory changes, the successor executives will face relatively severe problems. He needs to stabilize the enterprise's decline in a short period of time, and turn the enterprise's operating performance into profit [19]. The accounting treatment of R\&D investment will enable the executives to reduce $R \& D$ investment preferentially when facing the improvement of short-term performance, and the long-term and unknown effect expenditures such as R\&D investment will be affected. To spread. By such means, we can get the approval of the board of directors, invest the limited financial resources of the enterprise in the Department with the best profitability rather than the research and development, which will increase the book value of the enterprise to a certain extent, and reach the expectation of the board of directors. Based on this, we propose the hypothesis:

Hypothesis 2A: when an enterprise changes its executives, the tendency of long-term risk decision-making in that year will be reduced, that is, the investment in $\mathrm{R} \& \mathrm{D}$ will be reduced.

Forced change means that the order established by the former executives of the enterprise will be replaced by a new order. According to the anomie theory, before the new order is completely established, the successor executives will adopt radical strategies. At this time, bribery and other acts will become the lifesaving straw of the successor executives [18]. As a kind of dark box operation, 
we can find that bribery acts as a lubricant in Chinese human relations, which can turn back the adverse situation of enterprises in a short period of time [2] [20]. Although such behavior will disturb the market order, the principal-agent theory holds that in order to achieve their own purposes, agents will take all the actions they can take. Therefore, we have reason to believe that after the mandatory change of executives, the successor executives are more inclined to adopt this kind of immediate risk decision-making which has quick effect but damages the corporate image and destroys the market order.

Based on this, we propose the hypothesis:

Hypothesis 2B: when the company changes its executives, the tendency of immediate risk decision-making will increase, that is, the short-term investment will increase.

\subsection{Regulatory Role of Succession Sources}

There are two sources of succession: one is directly promoted from within the enterprise, the other is hired from outside [13]. In the aspect of political governance, some studies have shown that the measures taken by the local and external leaders in the face of the same political events are quite different. Often, the internal leaders will adopt moderate measures that are conducive to the long-term governance of the township, while the external leaders will adopt violent suppression and other short-term effective means [14]. Wang Lina found that the successor executives from the outside have a higher tendency to change the corporate strategy. Specifically, if the successor executives are promoted from the inside of the enterprise, then they have a better understanding of the situation of the enterprise, so there will be some consistency in the decision-making. On the contrary, if the successor executives come from the outside, then they will be innovative when making decisions [13] [21].

Hypothesis 3A: in the enterprises with the change of executives, the successor executives from the outside will reduce the intensity of $R \& D$ investment, the successor executives from the inside will increase the intensity of R\&D investment.

Hypothesis 3B: in the enterprise with the change of executives, the external successor executives will reduce the intensity of short-term investment, the internal successor executives will increase the intensity of short-term investment.

Similar to the external chief executive who used rude repression in political events [14], in the enterprises where the change of executives was forced, the successor executives would tend to take irrational actions such as bribery to solve short-term problems.

Because of the urgency of the problem, the external successor executives will try to solve the problem. However, increasing the expenditure of irrational activities such as bribery will have an impact on the reputation of the enterprise. In addition, because the external successor executives have not participated in the decision-making activities before the enterprise, and have fewer relationships in the enterprise, the factors restricting his/her behavior are less [22] [23]. On the 
contrary, if the successor comes from the inside of the enterprise, he/she will use relatively moderate means to solve the problem. In order to maintain the consistency of policies, the expenditure of irrational activities such as entertainment consumption will increase relatively.

Based on this, the hypothesis is put forward.

Hypothesis 4A: in the enterprises with mandatory executive change, the successor executives from outside will reduce the R\&D investment, the successor executives from inside will increase the $R \& D$ investment intensity.

Hypothesis 4B: in the enterprises with mandatory change of executives, the external successor executives will reduce the intensity of short-term investment, the internal successor executives will increase the intensity of short-term investment.

\section{Models and Variables}

\subsection{Models}

$$
\begin{aligned}
\text { Long }_{t}= & \alpha_{1} \operatorname{Dit}_{t-1}+\alpha_{2} \operatorname{Dir}_{t-1}+\alpha_{3} \operatorname{Dit}_{t-1} * \operatorname{Dir}_{t-1}+\beta_{1} D i f_{t-1} \\
& +\beta_{2} \operatorname{Dir}_{t-1}+\beta_{3} \operatorname{Dif}_{t-1} * D i r_{t-1}+\text { control }+\varepsilon \\
\text { Short }_{t}= & \alpha_{1} \operatorname{Dit}_{t-1}+\alpha_{2} \operatorname{Dir}_{t-1}+\alpha_{3} \operatorname{Dit}_{t-1} * D i r_{t-1}+\beta_{1} D i f_{t-1} \\
& +\beta_{2} \operatorname{Dir}_{t-1}+\beta_{3} D i f_{t-1} * D i r_{t-1}+\text { control }+\varepsilon
\end{aligned}
$$

\begin{tabular}{|c|c|}
\hline Variables & Table column subhead \\
\hline Short & Short-term investment \\
\hline Long & Long-term investment \\
\hline Change & Change of chairman or general \\
\hline Force & Chairman or general manager forced change \\
\hline Dchange & Chairman change \\
\hline Dforce & Chairman's mandatory change \\
\hline Dr & Chairman's successor source \\
\hline Zchange & General manager change \\
\hline Zforce & General manager mandatory change \\
\hline $\mathrm{Zr}$ & General manager successor source \\
\hline Age & Business age \\
\hline Size & Business scale \\
\hline Boardscale & Number of board members \\
\hline Diage & Age \\
\hline Disex & Gender \\
\hline Slack & Redundant resources \\
\hline
\end{tabular}

Table 1 is the specific meaning of the variables.

Table 1. The meaning of the variables. 


\subsection{Variables Measurement}

\subsubsection{Explained Variable}

Risk decision tendency includes long-term and short-term investments in R\&D investment. Referring to the research of Xu [18], long-term risk decision-making is defined as the intensity of R\&D investment of enterprises, real-time risk decision-making is defined as the abnormal expenditure of enterprises. The abnormal expenditure of an enterprise is measured by a model. Generally speaking, we think that the travel expenses and business entertainment expenses of an enterprise are composed of the top three executive compensation, total sales, total assets, sales expense rate and capital intensity. According to the research of CAI [24], the last four variables are the normal operating expenditure of an enterprise. The top three executive compensation includes the abnormal expenditure of an enterprise. We use this company. The residual is used to represent the abnormal expenditure of the enterprise, that is, the immediate risk decision. The empirical results show that the travel expenses and business entertainment expenses of enterprises are highly correlated with the five variables mentioned above $(P<0.01)$, which has a certain degree of credibility compared with the destructive activities such as Information Disclosure Violation and operation violation published by enterprises themselves in the capital market.

\subsubsection{Explanatory Variable}

Executive changes dif. Referring to the research of Lin Yongjian [25], the change of senior management is defined as the change of chairman or general manager. The change of chairman is divided into change and forced change, and the change of general manager is divided into change and forced change. Referring to the research of Pan Yue [26], Liu Xing [27], etc., we define the job transfer, resignation, dismissal, personal reasons and other types of executive change as force. In addition, we define whether the chairman of the board of directors changes/changes compulsively as (dchange/dforce), and whether the general manager changes/changes compulsively as (zchange/zforce).

\subsubsection{Adjustment Variable}

Succession source (resource), referring to the research of Hou [14], etc., is divided into two different dimensions: internal promotion and external transfer, which are divided into chairman succession source (DR) and general manager succession source $(\mathrm{Zr})$.

\subsubsection{Control Variables}

According to the previous research literature, the control variables mainly include the following: 1) age after the listing of the enterprise, 2) size of the enterprise scale, the natural logarithm of the total assets of the enterprise at the end of the period, 3) slack, expressed by dividing the current assets of the enterprise by the total liabilities, 4) age of senior executives, age of the chairman as of the reporting period, 5) board of directors, board scale, in terms of number of directors. In addition, this paper also set up industry dummy variables and annual 
dummy variables to control industry differences and the impact of annual changes on senior managers' risk decision-making preferences.

\subsection{Theoretical Model}

Figure 1 details the hypothesis of this paper. The specific relationship between executive change and mandatory executive change for short-term and long-term investments needs to be explored.

\section{Empirical Analysis}

\subsection{Research Data}

The research object of this paper is the private listed companies with independent management rights. With the improvement of market supervision system and the demand of the development of enterprises themselves, the event of senior management change in such enterprises is more and more common. According to the research needs of this paper, the samples of St, st ${ }^{*}$ and other companies, financial listed companies such as securities, banks and insurance companies, and enterprises with abnormal asset liability ratio and poor management are excluded.

The data in this paper mainly comes from CSMAR database, which is an authoritative database in China. After deleting the seriously missing samples, we finally obtained the observation values in 2006-2017. The samples mainly include manufacturing industry, construction industry, wholesale and retail industry, etc. At the same time, in order to eliminate the interference of outliers, $1 \%$ tailing of continuous variables is done.

The correlation test is shown in the table (Table 2). It can be seen from the table that the correlation coefficient of each variable is generally low, and the highest correlation coefficient is 0.61 (whether the senior managers change or not and the senior managers force change). In order to test the degree of multicollinearity of the model, we test the variance expansion coefficient (VIF) of each model. In this model, the maximum expansion coefficient is 1.15 , which is far lower than the reference standard 10 , so there is no serious collinearity problem. Descriptive statistics and correlation analysis are shown in Table 3.

\subsection{Multiple Regression Results}

The regression results are reported in Table 4. Considering the heteroscedasticity and timing of panel data, the model estimation results deviate from the real values, and the Driscoll Kray standard deviation is used for estimation. Model 1 and model 2 in Table 3 explore the impact of the change of chairman or general manager on enterprise risk decision-making. The results show that the change of chairman or general manager can significantly reduce the long-term R\&D investment of the enterprise $(\beta=-0.421, P<0.01)$, but the impact on short-term investment is not significant $(P>0.1)$. Suppose $1 \mathrm{a}$ is verified, $1 \mathrm{~b}$ is not verified. 


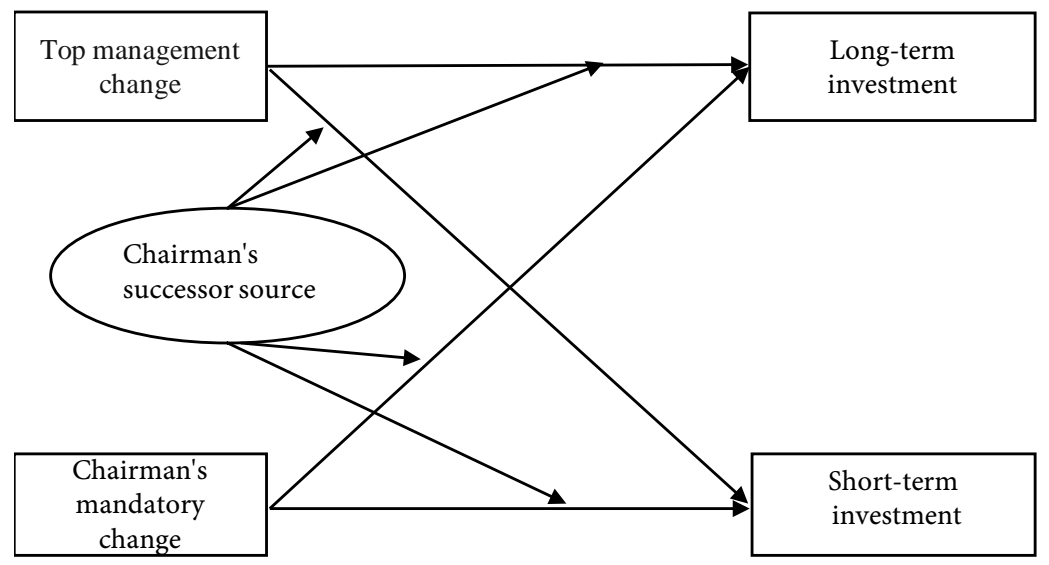

Figure 1. Theoretical model.

Table 2. Descriptive statistics.

\begin{tabular}{ccc}
\hline Variables & Mean & SD \\
\hline Short & 0.02 & 0.70 \\
Long & 4.83 & 4.46 \\
Change & 0.170 & 0.370 \\
Force & 0.08 & 0.28 \\
Dchange & 0.07 & 0.25 \\
Dforce & 0.03 & 0.16 \\
Dr & 0.02 & 0.14 \\
Zchange & 0.14 & 0.35 \\
Zforce & 0.07 & 0.26 \\
Zr & 0.20 & 0.49 \\
Age & 1 & 0.65 \\
Size & 9.36 & 0.43 \\
Boardscale & 8.26 & 1.46 \\
Diage & 51.3 & 8.57 \\
Disex & 0.91 & 0.29 \\
Slack & 1.15 & 1.01 \\
\hline
\end{tabular}

Model 3 and model 4 explore the impact of mandatory change of chairman or general manager on enterprise risk decision-making. The results show that mandatory change of chairman or general manager can significantly reduce long-term R\&D investment $(\beta=-0.288, P<0.1)$, and significantly increase short-term investment $(\beta=0.0574, P<0.01)$. Hypothesis $2 \mathrm{a}$ and $2 \mathrm{~b}$ are verified.

Table 5 reports the regression results. All models adopt fixed effect model, in which model 1-1 explores the relationship between senior management change and R\&D investment time of enterprises. The results show that senior management change can reduce R\&D investment of enterprises $(\beta=-0.254, P<0.1)$. Hypothesis la is verified. 
Table 3. Correlation analysis.

\begin{tabular}{|c|c|c|c|c|c|c|c|c|c|c|}
\hline Variables & 1 & 2 & 3 & 4 & 5 & 6 & 7 & 8 & 9 & 10 \\
\hline Short & 1 & & & & & & & & & \\
\hline Long & 0.174 & 1 & & & & & & & & \\
\hline Change & -0.001 & -0.049 & 1 & & & & & & & \\
\hline Force & 0.017 & -0.02 & 0.68 & 1 & & & & & & \\
\hline Slack & 0.013 & 0.180 & -0.02 & -0.04 & 1 & & & & & \\
\hline Age & -0.028 & -0.035 & -0.05 & -0.059 & 0.039 & 1 & & & & \\
\hline Size & -0.006 & -0.236 & 0.064 & 0.055 & -0.22 & -0.25 & 1 & & & \\
\hline Boardscale & 0.03 & -0.068 & 0.004 & -0.02 & -0.07 & 0.078 & 0.155 & 1 & & \\
\hline Diage & -0.037 & -0.057 & -0.04 & -0.029 & -0.01 & -0.11 & 0.068 & 0.077 & 1 & \\
\hline Disex & 0.022 & -0.002 & 0.006 & 0.010 & -0.02 & 0.038 & -0.00 & 0.039 & 0.118 & 1 \\
\hline
\end{tabular}

Table 4. The regression results.

\begin{tabular}{|c|c|c|c|c|}
\hline & Long & Short & Long & Short \\
\hline & Mode 1-1 & Mode 1-2 & Model 1-3 & Mode1-4 \\
\hline \multirow{2}{*}{ Change } & $-0.421^{\star * *}$ & 0.00866 & & \\
\hline & $(0.161)$ & $(0.0153)$ & & \\
\hline \multirow{2}{*}{ Force } & & & $-0.288^{*}$ & $0.0574^{\star \star \star}$ \\
\hline & & & $(0.210)$ & $(0.0219)$ \\
\hline \multirow{2}{*}{ Age } & $6.768^{* * *}$ & $-0.114^{\star * *}$ & $6.816^{* * *}$ & $-0.112^{\star * *}$ \\
\hline & $(0.579)$ & $(0.0278)$ & $(0.598)$ & $(0.0277)$ \\
\hline \multirow{2}{*}{ Size } & $-1.630^{\star * *}$ & $0.0186^{* *}$ & $-1.641^{\star * *}$ & $0.0176^{\star *}$ \\
\hline & $(0.113)$ & $(0.00825)$ & $(0.117)$ & $(0.00834)$ \\
\hline \multirow{2}{*}{ Slack } & $0.603^{* * *}$ & $0.0116^{*}$ & $0.602^{\star * *}$ & $0.0119^{*}$ \\
\hline & $(0.172)$ & $(0.00621)$ & $(0.175)$ & $(0.00634)$ \\
\hline \multirow{2}{*}{ Diage } & -0.00898 & $-0.00321^{* * *}$ & -0.00860 & $-0.00317^{* * *}$ \\
\hline & $(0.00758)$ & $(0.000939)$ & $(0.00743)$ & $(0.000957)$ \\
\hline \multirow{2}{*}{ Boardscale } & -0.00169 & $0.0254^{* * *}$ & -0.00274 & $0.0257^{* * *}$ \\
\hline & $(0.0431)$ & $(0.00240)$ & $(0.0438)$ & $(0.00251)$ \\
\hline Industry & Yes & Yes & Yes & Yes \\
\hline Year & Yes & Yes & Yes & Yes \\
\hline \multirow{2}{*}{ Constant } & $6.339^{* *}$ & $12.72^{\star * *}$ & $-1.416^{* * *}$ & $-1.786^{* * *}$ \\
\hline & $(2.979)$ & $(2.888)$ & $(0.422)$ & $(0.409)$ \\
\hline Observations & 6081 & 6081 & 6081 & 6081 \\
\hline R-squared & 0.286 & 0.022 & 0.286 & 0.022 \\
\hline Number of id & 1519 & 1519 & 1519 & 1519 \\
\hline
\end{tabular}

$*, * *, * *$ indicate significant levels at $10 \%, 5 \%$, and $1 \%$, respectively. 
Table 5. The chairman changes the role of relaying the source of regulation.

\begin{tabular}{|c|c|c|c|c|c|c|c|c|}
\hline & Long & Long & Long & Long & Short & Short & Short & Short \\
\hline & Model & Model & Model & Model & Model & Model & Model & Model \\
\hline & $1-1$ & $1-2$ & $1-3$ & $1-4$ & $2-1$ & $2-2$ & $2-3$ & $2-4$ \\
\hline \multirow{2}{*}{ Dchange } & $-0.254^{\star}$ & -0.0214 & $-0.289^{\star}$ & -0.0230 & -0.0152 & 0.0069 & $0.0515^{\star}$ & $0.094^{\star *}$ \\
\hline & $(0.136)$ & $(0.159)$ & $(0.15)$ & $(0.18)$ & $(0.02)$ & $(0.02)$ & $(0.03)$ & $(0.038)$ \\
\hline \multirow{2}{*}{ Dr } & & -0.410 & & $-0.42^{\star \star}$ & & $0.16^{* * *}$ & & $0.13^{* * *}$ \\
\hline & & $(0.254)$ & & $(0.17)$ & & $(0.037)$ & & $(0.034)$ \\
\hline \multirow{2}{*}{$\begin{array}{c}\text { Dchange } \times \\
\text { Dr }\end{array}$} & & $-0.701^{* *}$ & & $-0.652^{\star *}$ & & $-0.13^{* * *}$ & & $-0.165^{* *}$ \\
\hline & & $(0.319)$ & & $(0.33)$ & & $(0.045)$ & & $(0.067)$ \\
\hline \multirow{2}{*}{ Age } & -0.699 & -0.706 & -0.623 & -0.638 & -0.047 & -0.042 & $-0.35^{\star * *}$ & $-0.34^{\star * *}$ \\
\hline & $(0.944)$ & $(0.943)$ & $(0.67)$ & $(0.67)$ & $(0.14)$ & $(0.135)$ & $(0.09)$ & $(0.096)$ \\
\hline \multirow{2}{*}{ Size } & $-0.461^{\star *}$ & $-0.461^{\star *}$ & $-0.35^{\star \star}$ & $-0.37^{\star \star}$ & $0.16^{\star *}$ & $0.169^{* * *}$ & $0.178^{\star * *}$ & $0.182^{\star * *}$ \\
\hline & $(0.231)$ & $(0.231)$ & $(0.16)$ & $(0.16)$ & $(0.03)$ & $(0.033)$ & $(0.03)$ & $(0.03)$ \\
\hline \multirow{2}{*}{ Slack } & $0.253^{\star * *}$ & $0.263^{* * *}$ & $0.254^{* * *}$ & $0.265^{\star * *}$ & -0.01 & -0.012 & -0.01 & -0.011 \\
\hline & $(0.05)$ & $(0.05)$ & $(0.05)$ & $(0.05)$ & $(0.01)$ & $(0.007)$ & $(0.007)$ & $(0.007)$ \\
\hline \multirow{2}{*}{ Diage } & -0.006 & -0.0067 & $-0.005^{*}$ & $-0.005^{\star}$ & 0.0006 & 0.0007 & 0.0008 & 0.0009 \\
\hline & $(0.004)$ & $(0.004)$ & $(0.003)$ & $(0.003)$ & $(0.001)$ & $(0.001)$ & $(0.001)$ & $(0.0006)$ \\
\hline \multirow{2}{*}{ Boardscale } & $0.11^{\star \star \star}$ & $0.11^{\star \star \star}$ & $0.11^{\star \star \star}$ & $0.11^{\star * \star}$ & $-0.013^{\star *}$ & $-0.013^{\star *}$ & $-0.015^{\star \star}$ & $-0.015^{\star *}$ \\
\hline & $(0.042)$ & $(0.042)$ & $(0.029)$ & $(0.029)$ & $(0.0059)$ & $(0.0059)$ & $(0.0059)$ & $(0.0059)$ \\
\hline Industry & Yes & Yes & Yes & Yes & Yes & Yes & Yes & Yes \\
\hline Year & Yes & Yes & Yes & Yes & Yes & Yes & Yes & Yes \\
\hline \multirow{2}{*}{ Constant } & $7.285^{\star *}$ & $7.093^{* *}$ & $5.49^{\star *}$ & $5.67^{\star *}$ & $-2.37^{\star * *}$ & $-2.47^{\star * *}$ & $-1.44^{\star * *}$ & $-1.5^{* * *}$ \\
\hline & (3.355) & $(3.35)$ & $(2.37)$ & $(2.37)$ & $(0.48)$ & $(0.48)$ & $(0.43)$ & $(0.425)$ \\
\hline Observations & 6081 & 6081 & 6081 & 6081 & 6081 & 6081 & 6081 & 6081 \\
\hline R-squared & 0.016 & 0.019 & 0.017 & 0.020 & 0.041 & 0.045 & 0.042 & 0.045 \\
\hline Number of id & 1519 & 1519 & 1519 & 1519 & 1519 & 1519 & 1519 & 1519 \\
\hline
\end{tabular}

*,**, *** indicate significant levels at $10 \%, 5 \%$, and $1 \%$, respectively.

In model 1-2, the independent variable is whether the executives change or not, and the dependent variable is the R\&D investment, which regulates the source of variable succession. It is assumed that the change of senior managers will reduce the R\&D investment of enterprises, and this effect will be regulated by the source of succession of senior managers. The source of succession comes from the outside, which will aggravate the reduction of R\&D investment caused by the change of senior managers. The results show that the reduction of $R \& D$ investment caused by the change of senior managers is regulated by the source of succession $(\beta=-0.701, P<0.05)$. Hypothesis $3 \mathrm{~B}$ passes the test.

Model 1-3 corresponds to the impact of executive forced change on long-term investment. The independent variable is executive forced change, and the dependent variable is long-term investment. Suppose $2 \mathrm{~A}$ thinks that as a coercive 
means, executive forced change can significantly reduce the long-term investment of enterprises, which has been confirmed $(\beta=-0.289, P<0.1)$.

Model 1-4 shows that executive succession sources positively regulate the relationship between executive forced change and long-term investment of enterprises, and that succession sources come from external sources, which can aggravate the negative impact of executive forced change on $\mathrm{R} \& \mathrm{D}$ investment. This point has also been confirmed $(\beta=-0.652, P<0.1)$. False $4 \mathrm{~B}$ passed the test and regulation effect passed the test.

In model 2-1, the change of senior managers is an independent variable and the short-term investment is a dependent variable. The results show that the change of senior managers cannot be increased. The short-term investment of enterprises $(\beta=-0.0152, P>0.1)$, assuming that $1 \mathrm{~b}$ fails the test.

Model 2-2 verifies that the source of succession can regulate the positive effect of executive change on short-term investment. The results show that the regulatory effect is significant $(\beta=-0.13, P<0.05)$. Model $2-3$ verifies that enterprises with mandatory change of executives will increase short-term investment compared with enterprises without mandatory change. After testing $(\beta=0.0515, P<$ $0.1)$, it shows that mandatory change of executives will significantly increase short-term investment of enterprises, which is consistent with our hypothesis 2B. In addition, we think that the source of executive succession negatively regulates the relationship between executive forced change and short-term investment of the enterprise. The executive power of internal executives is stronger than that of external executives, so the internal successor will continue to increase such short-term investment. Model 2-4 shows that this part of the regulatory effect is significant. Suppose $4 \mathrm{~B}$ passes the test $(\beta=-0.165, P<0.05)$.

\subsection{Multiple Regression Results of PSM}

Considering whether a company's executives are subject to change is conditional, it is random for a company to have executive changes. In order to solve this problem, we have chosen a more common method of propensity matching in management research to solve this problem (Choi et al., 2014, Heather \& Nan, 2014), propensity score matching by matching samples (executive change, Force executives to change and not change) to reduce endogeneity, in this way to eliminate false results due to independent variables. Using a multiple regression model, first predict the possibility of executive change and mandatory change in the enterprise, use PSM to calculate the propensity score of each observation sample, whether the predicted probability of change occurs, and what type of change occurs, and score based on whether a matching sample of mandatory changes occurs. The matched samples were subjected to fixed-effect regression using a radius matching method.

Table 6 and Table 7 report the regression results. All models use a fixed-effects model to explore the relationship between executive change and enterprise $R \& D$ investment time. The results show that executive change will reduce the company's $R \& D$ investment $(\beta=-0.256, p<0.1)$. Assume that 1 a is verified. 
Table 6. The PSM results.

\begin{tabular}{|c|c|c|c|c|}
\hline & Long & Long & Short & Short \\
\hline & Model 1-5 & Model 1-6 & Model 2-5 & Model 2-6 \\
\hline \multirow{2}{*}{ Dchange } & $-0.256^{*}$ & -0.022 & -0.014 & 0.0128 \\
\hline & $(0.135)$ & $(0.159)$ & $(0.0195)$ & $(0.0229)$ \\
\hline \multirow{2}{*}{ Dr } & & $-0.421^{*}$ & & $0.153^{* * *}$ \\
\hline & & $(0.253)$ & & $(0.0361)$ \\
\hline \multirow[t]{2}{*}{ Dchange $\times$ Dr } & & $-0.699^{* *}$ & & $-0.105^{\star *}$ \\
\hline & & $(0.318)$ & & $(0.0447)$ \\
\hline \multirow{2}{*}{ Age } & -0.729 & -0.739 & $-0.347^{* * *}$ & $-0.343^{* * *}$ \\
\hline & $(0.945)$ & $(0.944)$ & $(0.0963)$ & $(0.0961)$ \\
\hline \multirow{2}{*}{ Size } & $-0.485^{\star *}$ & $-0.490^{\star *}$ & $0.180^{* * *}$ & $0.185^{* * *}$ \\
\hline & $(0.228)$ & $(0.228)$ & $(0.0329)$ & $(0.0328)$ \\
\hline \multirow{2}{*}{ Slack } & $-1.294^{* * *}$ & $-1.309^{* * *}$ & $0.0789^{\star}$ & $0.0838^{\star}$ \\
\hline & $(0.322)$ & $(0.322)$ & $(0.0461)$ & $(0.0460)$ \\
\hline \multirow{2}{*}{ Diage } & $0.0954^{* *}$ & $0.0924^{\star *}$ & $-0.0154^{\star * *}$ & $-0.0148^{\star *}$ \\
\hline & $(0.0413)$ & $(0.0413)$ & $(0.00595)$ & $(0.00594)$ \\
\hline \multirow{2}{*}{ Boardscale } & $-0.00805^{\star}$ & $-0.00834^{\star}$ & 0.000816 & 0.000894 \\
\hline & $(0.00439)$ & $(0.00438)$ & $(0.000634)$ & $(0.000633)$ \\
\hline Industry & Yes & Yes & Yes & Yes \\
\hline Year & Yes & Yes & Yes & Yes \\
\hline \multirow{2}{*}{ Constant } & $7.531^{\star *}$ & $7.619^{* * *}$ & $-1.459^{* * *}$ & $-2.635^{\star * *}$ \\
\hline & $(2.950)$ & $(2.950)$ & $(0.426)$ & $(0.483)$ \\
\hline Observations & 6184 & 6184 & 6184 & 6184 \\
\hline R-squared & 0.015 & 0.017 & 0.041 & 0.045 \\
\hline Number of id & 1549 & 1549 & 1554 & 1554 \\
\hline
\end{tabular}

$*^{*}, * *, * *$ indicate significant levels at $10 \%, 5 \%$, and $1 \%$, respectively.

In model 1-6, the independent variable is whether the executive is changed, the dependent variable is the $\mathrm{R} \& \mathrm{D}$ input, and the variable variable is the successor source. It is assumed that the change of executives will reduce the R\&D investment of the company. This effect will be regulated by the successor source of the executives. The successor source will come from the outside, which will aggravate the reduction of $R \& D$ investment caused by the change of senior management. The reduction is regulated by the successor source $(\beta=-0.699, P<$ $0.05)$, assuming that $3 \mathrm{~b}$ passes the test.

Model 1-7 corresponds to the effect of executive change on long-term input, and the independent variable is executive change, dependent variable For long-term investment. Hypothesis 2a believes that executive change is a mandatory means that can significantly reduce long-term investment in the firm, which 
Table 7. The PSM results.

\begin{tabular}{|c|c|c|c|c|}
\hline & Long & Long & Short & Short \\
\hline & Model 1-7 & Model 1-8 & Model 2-7 & Model 2-8 \\
\hline \multirow{2}{*}{ Dchange } & $-0.453^{\star}$ & -0.00403 & $0.0515^{*}$ & $0.0933^{* *}$ \\
\hline & $(0.215)$ & $(0.265)$ & $(0.0311)$ & $(0.0382)$ \\
\hline \multirow{2}{*}{ Dr } & & $-0.523^{* *}$ & & $0.124^{* * *}$ \\
\hline & & $(0.239)$ & & $(0.0341)$ \\
\hline \multirow[t]{2}{*}{ Dchange $\times$ Dr } & & $-1.150^{* *}$ & & $-0.161^{\star *}$ \\
\hline & & $(0.461)$ & & $(0.0666)$ \\
\hline \multirow{2}{*}{ Age } & -0.709 & -0.727 & $-0.342^{\star * *}$ & $-0.339^{* * *}$ \\
\hline & $(0.946)$ & $(0.945)$ & $(0.0962)$ & $(0.0961)$ \\
\hline \multirow{2}{*}{ Size } & $-0.432^{\star}$ & $-0.445^{\star}$ & $0.196^{\star * *}$ & $0.199^{\star * *}$ \\
\hline & $(0.230)$ & $(0.230)$ & $(0.0330)$ & $(0.0330)$ \\
\hline \multirow{2}{*}{ Slack } & $-1.293^{* * *}$ & $-1.320^{* * *}$ & $0.0864^{*}$ & $0.0873^{\star}$ \\
\hline & $(0.324)$ & $(0.324)$ & $(0.0464)$ & $(0.0463)$ \\
\hline \multirow{2}{*}{ Diage } & $0.0917^{\star *}$ & $0.0889^{* *}$ & $-0.0148^{\star *}$ & $-0.0143^{* *}$ \\
\hline & $(0.0416)$ & $(0.0416)$ & $(0.00597)$ & $(0.00597)$ \\
\hline \multirow{2}{*}{ Boardscale } & $-0.00797^{\star}$ & $-0.00846^{*}$ & 0.000873 & 0.000943 \\
\hline & $(0.00439)$ & $(0.00439)$ & $(0.000633)$ & $(0.000633)$ \\
\hline Industry & Yes & Yes & Yes & Yes \\
\hline Year & Yes & Yes & Yes & Yes \\
\hline \multirow{2}{*}{ Constant } & $6.983^{* *}$ & $7.172^{* *}$ & $-1.620^{\star * *}$ & $-1.674^{* * *}$ \\
\hline & (3.345) & $(3.342)$ & $(0.427)$ & $(0.427)$ \\
\hline Observations & 6157 & 6157 & 6157 & 6157 \\
\hline R-squared & 0.015 & 0.017 & 0.043 & 0.046 \\
\hline Number of id & 1543 & 1543 & 1548 & 1548 \\
\hline
\end{tabular}

${ }^{*},{ }^{* *},{ }^{* *}$ indicate significant levels at $10 \%, 5 \%$, and $1 \%$, respectively.

is confirmed $(\beta=-0.453, P<0.1)$. In addition, models $1-8$ indicate that the successor source of the executive is positive. The relationship between the mandatory change of executives and the long-term investment of the company, the successor source from the outside, can aggravate the negative impact of executive change on $\mathrm{R} \& \mathrm{D}$ investment, as shown in figure $(\beta=-1.150, P<0.05)$, assuming that $4 \mathrm{~b}$ passes the test, the regulatory effect is verified by the test.

\subsection{Robustness Test}

There are some missing data on the dependent variable $R \& D$ input, so we use the Heckman two-step method to first predict the selection model of the enterprise $R \& D$ investment, and use probit to estimate the probability that the sample is selected. This probability is the inverse Mills coefficient. The inverse Mills 
coefficient is brought into the main model to solve the problem of missing observations.

Table 8 shows the results of multiple regression. Model 1 uses probit estimation, where the independent variables are firm size, asset-liability ratio, time to market, redundant resources, shareholding ratio, and the dependent variable is whether R\&D investment is selected. The results show that the respective variables are highly correlated with the dependent variables. Subsequent model 2-1 makes the impact of whether the executive changes on the R\&D investment in the case of adding the inverse Mills coefficient. The fixed effect model is used, and the results indicate that the executives the change will reduce the company's R\&D investment $(\beta=-0.287, P<0.05)$, so assume that 1 passes the test.

Models 1-10 also use fixed-effect models. The independent variables are whether the executives change, the dependent variables are R\&D inputs, and the regulatory variable relay sources. It is assumed that the change of executives will reduce the $\mathrm{R} \& \mathrm{D}$ investment of the company. This effect will be regulated by the successor source of the executives. The successor source will come from the outside, which will aggravate the reduction of $\mathrm{R} \& \mathrm{D}$ investment caused by the change of senior management. The reduction was regulated by the successor source ( $\beta=$ $-0.485, P<0.1$ ), assuming that $3 \mathrm{~b}$ passed the test.

Model 1-9 corresponds to the impact of executive change on long-term investment, the independent variable is mandatory change of the executive, and the dependent variable is long-term input. Hypothesis 1a believes that executive change is a mandatory means that can significantly reduce long-term investment in the firm, which is confirmed $(\beta=-0.415, P<0.1)$. In addition, model $2-4$ indicates that the successor source of the executive is positive. The relationship between the mandatory change of executives and the long-term investment of the company, the source of succession from the outside, can aggravate the negative impact of executive change on $\mathrm{R} \& \mathrm{D}$ investment, as shown in figure $(\beta=$ $-0.791, P<0.1$ ), assuming that 3 passes the test, the adjustment effect passes the test. In addition, the models 1-9 also support the conclusion of the model 1-1, indicating that the sample after the tendency matching can also prove that the executive change can significantly reduce the enterprise. Long-term $R \& D$ investment $(\beta=-0.609, P<0.1)$.

Models 2-13 through 2-17 verify the impact of executive change and executive change on the company's short-term investment.

In model 2-9, executive change is used as an independent variable and short-term input is used as a dependent variable. It does not increase the short-term investment of the company $(\beta=0.000487, P>0.1)$. Model 2-10 verifies that executive successor sources can modulate the positive impact of executive changes on short-term inputs, and the results indicate that the regulatory effects are not significant $(P>0.1)$. Model 3-3 verifies that companies with mandatory executive changes will increase short-term investments compared to those that do not have mandatory changes. After testing $\beta=0.0515, P<0.1$, 
Table 8. The impact of executive change on the types of enterprise risk decisions.

\begin{tabular}{|c|c|c|c|c|c|}
\hline & $\mathrm{R} \& \mathrm{D}$ & Long & Long & Short & Short \\
\hline & & Model 1-9 & Model 1-10 & Model 2-9 & Model 2-10 \\
\hline \multirow{2}{*}{ Dchange } & & $-0.287^{\star \star}$ & -0.166 & & \\
\hline & & $(-0.137)$ & $(-0.155)$ & & \\
\hline \multirow[t]{2}{*}{ Dchange $\times$ Dr } & & & $-0.485^{\star}$ & & \\
\hline & & & $(-0.291)$ & & \\
\hline \multirow{2}{*}{ Dforce } & & & & $-0.415^{*}$ & -0.206 \\
\hline & & & & $(-0.217)$ & $(-0.251)$ \\
\hline \multirow[t]{2}{*}{ Dforce $\times$ Dr } & & & & & $-0.791^{*}$ \\
\hline & & & & & $(-0.479)$ \\
\hline \multirow{2}{*}{ Age } & $-0.739^{* * *}$ & -0.72 & -0.715 & -0.711 & -0.706 \\
\hline & $(-0.112)$ & $(-0.949)$ & $(-0.949)$ & $(-0.949)$ & $(-0.949)$ \\
\hline \multirow{2}{*}{ Size } & 0.136 & $-0.467^{\star \star}$ & $-0.460^{\star \star}$ & $-0.459^{\star *}$ & $-0.449^{*}$ \\
\hline & $(-0.137)$ & $(-0.229)$ & $(-0.229)$ & $(-0.229)$ & $(-0.229)$ \\
\hline \multirow{2}{*}{ Slack } & $-1.040^{* * *}$ & $-1.311^{* * *}$ & $-1.312^{\star * *}$ & $-1.310^{* * *}$ & $-1.317^{* * *}$ \\
\hline & $(-0.288)$ & $(-0.33)$ & $(-0.33)$ & $(-0.33)$ & $(-0.33)$ \\
\hline \multirow{2}{*}{ Diage } & & $-0.00772^{*}$ & $-0.00770^{*}$ & $-0.00729^{*}$ & $-0.00728^{\star}$ \\
\hline & & $(-0.0044)$ & $(-0.0044)$ & $(-0.00439)$ & $(-0.00439)$ \\
\hline Boardsize & & $\begin{array}{c}0.104^{* *} \\
(-0.0413)\end{array}$ & $\begin{array}{c}0.104^{\star *} \\
(-0.0413)\end{array}$ & $\begin{array}{c}0.102^{\star *} \\
(-0.0413)\end{array}$ & $\begin{array}{c}0.103^{* *} \\
(-0.0413)\end{array}$ \\
\hline Industry & & Yes & Yes & Yes & Yes \\
\hline Year & & Yes & Yes & Yes & Yes \\
\hline Constant & $2.233^{*}$ & $7.264^{* *}$ & $7.169^{* *}$ & $7.172^{\star *}$ & $7.037^{\star *}$ \\
\hline Constant & $(-1.296)$ & $(-2.961)$ & $(-2.961)$ & $(-2.96)$ & $(-2.96)$ \\
\hline Observations & 6350 & 6273 & 6273 & 6273 & 6273 \\
\hline R-squared & & 0.14 & 0.15 & 0.14 & 0.15 \\
\hline Number of id & & 1549 & 1549 & 1549 & 1549 \\
\hline
\end{tabular}

$*^{*}, * * * *$ indicate significant levels at $10 \%, 5 \%$, and $1 \%$, respectively.

indicating that executive change will significantly increase the short-term of the company. Investing, is consistent with our assumptions. In addition, we believe that the successor of the executives negatively regulates the relationship between executive change and short-term investment. The internal executives are more engaged in the company than the external successors, so the internal successor. This short-term investment will be mitigated as a weakening of the positive impact on short-term performance, and the end result indicates that this part of the adjustment effect hypothesis has not passed the test $(P>0.1)$. 


\section{Conclusions and Enlightenment}

In the context of the gradual warming of the economic situation, the occurrence of executive change events has increased year by year. As mentioned earlier in this article, executive changes will have an impact on the performance of the company. "New officials take up three fires". About whether such an event will happen or not, this article explores this phenomenon from the theoretical basis and empirical research. Unlike our imagination, executives change the phenomenon of "new officials taking three fires", but they are not in the direction that is conducive to the long-term development of enterprises:

1) Enterprises will reduce $R \& D$ investment. Companies with compulsory executive change are particularly significant, but such situations are regulated by the successor of executives. If the successor executives come from within, despite the change, the successor executives will be coherent in corporate decision-making and the long-term business. Develop and thus choose long-term investment.

2) The executive change will greatly increase the short-term investment of the company. This situation becomes more significant with the compulsory change of the executives. It is understandable that the short-term investment can reverse the business decline in the short term, becoming the most effective way for "new officials", although such decisions are risky.

Through the research in this paper, we link the change of executives with the specific decision-making behavior of the enterprise, and the traditional executive change will improve or reduce the overall performance (ROA, ROE) and so on. The risk decision-making tendency of successor executives in decision-making has brought a new explanation for the "new officials taking up three fires".

In addition, the conclusions of this paper link executive change and the type of risk decision-making of enterprises, enriching the research field of executive change, indicating that the type of risk decision-making of enterprises is largely affected by changes in executives of enterprises, and we find executives through the theory of anomie. After the change, the lack of the original order of the enterprise will be used by the successor executives to increase the short-term investment. This will bring us enlightenment. After the change, the enterprise should strengthen supervision and quickly establish a new order. Otherwise, the impact of these short-term investments will be brought. It will cause losses to the reputation of the company; based on the theory of real earnings management, successor executives will reduce $R \& D$ investment, which will also have an impact on the long-term development of the company. It is inspired by the selection of external successor executives. Reduce the reduction in $R \& D$ investment due to decision coherence.

\section{Conflicts of Interest}

The author declares no conflicts of interest regarding the publication of this paper. 


\section{References}

[1] Cohen, A.K. (1965) The Sociology of the Deviant Act: Anomie Theory and Beyond. American Sociological Review, 30, 5-14. https://doi.org/10.2307/2091770

[2] Martin, K.D., Cullen, J.B., Johnson, J.L. and Praveen Parboteeah, K. (2007) Deciding to Bribe: A Cross-Level Analysis of Firm and Home Country Influences on Bribery Activity. Academy of Management Journal, 50, 1401-1422.

https://doi.org/10.5465/amj.2007.28179462

[3] Moore, M.L. (1973) Management Changes and Discretionary Accounting Decisions. Journal of Accounting Research, 11, 100-107. https://doi.org/10.2307/2490283

[4] Defond, M.L. and Park, C.W. (1997) Smoothing Income in Anticipation of Future Earnings. Journal of Accounting \& Economics, 23, 115-139.

https://doi.org/10.1016/S0165-4101(97)00004-9

[5] Graham, J.R., Harvey, C.R. and Rajgopal, S. (2005) The Economic Implications of Corporate Financial Reporting. Journal of Accounting \& Economics, 40, 3-73. https://doi.org/10.1016/j.jacceco.2005.01.002

[6] Roychowdhury, S. (2006) Earnings Management through Real Activities Manipulation. Journal of Accounting \& Economics, 42, 335-370.

https://doi.org/10.1016/j.jacceco.2006.01.002

[7] Geertsema, P., Lont, D.H. and Lu, H. (2015) Real Earnings Management around CEO Turnovers. SSRN Electronic Journal.

[8] Zhu, X.W., Liao, Y.G. and Xie, S.W. (2010) Senior Manager Change, Equity Characteristics and Earnings Management-Empirical Evidence from Chinese Listed Companies. Nankai Management Review, 13, 23-29.

[9] Li, Z.F., Dong, Z.Q. and Lian, Y.J. (2011) Accrual Project Earnings Management or Real Activity Earnings Management?-Based on China's 2007 Income Tax Reform Research. Management World, No. 208, 129-142.

[10] Tihanyi, L., Ellstrand, A.E., Catherine M. Daily, Dan R. Dalton (2000) Composition of the Top Management Team and Firm International Diversification. Journal of Management, 26, 1157-1177. https://doi.org/10.1177/014920630002600605

[11] Liu, Y.L. (2014) An Empirical Study of the Impact of Vertical Verticality on Accounting Robustness in Managerial Teams. Nankai Management Review, 17, 107-116.

[12] Strong, J.S. and Meyer, J.R. (2012) Asset Writedowns: Managerial Incentives and Security Returns. Journal of Finance, 42, 643-661. https://doi.org/10.1111/j.1540-6261.1987.tb04574.x

[13] Du, X.Q. and Zhou, Z.J. (2010) Executive Change, Successor Source and Earnings Management. Contemporary Economic Science, 32, 23-33.

[14] Hou, L., Liu, M.X., Yang, D.L. and Xue, J. (2018) Of Time, Leadership, and Governance: Elite Incentives and Stability Maintenance in China. Governance, 31, 239-257. https://doi.org/10.1111/gove.12286

[15] Kellermanns, F.W. (2012) Innovativeness in Family Firms: A Family Influence Perspective. Small Business Economics, 38, 85-101. https://doi.org/10.1007/s11187-010-9268-5

[16] Lansberg, I. (2010) Passing the Baton: Managing the Process of CEO Succession, by Richard F. Vancil. Boston, MA: Harvard Business School Press, 1987, 318 pp. \$24.95. Human Resource Management, 27, 257-262. https://doi.org/10.1002/hrm.3930270210

[17] Cullen, J.B., Parboteeah, K.P. and Hoegl, M. (2004) Cross-National Differences in 
Managers' Willingness to Justify Ethically Suspect Behaviors: A Test of Institutional Anomie Theory. Academy of Management Journal, 47, 411-421. https://doi.org/10.5465/20159590

[18] Xu, D., Zhou, K. and Du, F. (2018) Deviant versus Aspirational Risk Taking: The Effects of Performance Feedback on Bribery Expenditure and R \& D Intensity. Academy of Management Journal, 62, 1226-1251.

[19] Ke, J.L., Zhang, B.W. and Sun, J.M. (2007) General Manager Replacement of Listed Companies, Executive Team Restructuring and Corporate Performance Improvement. Nankai Management Review, 10, 104-112.

[20] Birhanu, A.G., Gambardella, A. and Valentini, G. (2016) Bribery and Investment: Firm-Level Evidence from Africa and Latin America. Strategic Management Journal, 37, 1865-1877. https://doi.org/10.1002/smj.2431

[21] Wang, L.N. (2008) An Empirical Analysis of the Factors Affecting the Source of Successors in China. Productivity Research, No. 180, 78-80.

[22] Hambrick, D.C. and Mason, P.A. (1984) Upper Echelons: The Organization as a Reflection of Its Top Managers. The Academy of Management Review, 9, 193-206. https://doi.org/10.5465/amr.1984.4277628

[23] Li, X.C. and Su, X.H. (2001) General Manager Succession: Western Theory and Practice in China. Management World, No. 4, 145-152.

[24] Zhen, L.I. and Chen, H.F. (2011) Legal Regulation of Chinese Food Safety from Effectiveness of Law. Food \& Machinery, 54, 55-78.

[25] Lin, Y.J., Wang, Z.Q. and Li, M.L. (2013) Executive Change and Earnings Management: An Empirical Study Based on Accrual Project Control and Real Activity Manipulation. Nankai Management Review, 16, 4-14.

[26] Pan, Y., Dai, Y.Y. and Wei, S.Q. (2011) Are Institutional Investors “Colluding” with Listed Companies?-Based on the Analysis of Executive Involuntary Changes and Succession Selection Events. Nankai Management Review, 14, 69-81.

[27] Liu, X., Dai, B. and Hao, Y. (2012) Executive Power and Corporate Governance Efficiency: Based on the Perspective of Changes in Executives of State-Owned Listed Companies. Journal of Industrial Engineering and Engineering, 26, 1-12. 